\title{
The marketing audit - its use by South African companies
}

\author{
L.F. Pitt and P.G. Steyn \\ Department of Business Economics, University of Pretoria, Pretoria
}

R. Abratt

Graduate School of Business Administration, University of the Witwatersrand, Johannesburg

\begin{abstract}
The use of marketing audits is regarded as an integral part of the strategic marketing management process. The marketing audit is a comprehensive, systematic, independent, and periodic examination of a company's marketing environment, objectives. strategies, and activities with a view to determining problem areas and opportunities and recommending a plan of action to improve the company's marketing performance. This article reports the results of a study of marketing-audit practices in listed South African companies. More than half the respondents do not use the marketing audit and their reasons for not doing this are regarded as being indicative of a lack of strategic orientation. Independent auditors are used by the majority of companies utilizing the marketing audit, and objectivity and expertise are given as the main reasons for this. Those companies using the marketing audit generally regard it as important and as an integral tool of strategic marketing management. The conclusion is drawn that if the results of this study are indicative of the South African situation, the marketing audit has not been accorded its rightful place in business.

S. Afr. J. Bus. Mgmt. 1984, 15: 225-228
\end{abstract}

Die gebruik van ' $n$ bemarkingsoudit word beskou as ' $n$ belang. rike onderdeel van die strategiese bemarkingsbestuursproses. Die bemarkingsoudit kan beskou word as 'n volledige, sistematiese, onafhanklike en periodieke beskouing van 'n onderneming se bemarkingsomgewing, doelwitte, strategieè en aktiwiteite met die oogmerk om probleemareas asook geleenthede te identifiseer en dienooreenkomstig 'n plan van optrede saam te stel om die bemarkingsaksie te verbeter. Hierdie artikel doen verslag oor ' $n$ studie wat onderneem is in verband met die gebruik van bemarkingsoudits deur genoteerde Suid-Afrikaanse maatskappye. Meer as die helfte van die respondente gebruik nie ' $n$ bemarkingsoudit nie en die redes daarvoor verstrek kan beskou word as ' $n$ aanduiding van ' $n$ gebrek aan strategiese oriëntasie. Onafhanklike ouditeurs word gebruik deur die meerdemeid ondernemings wat wel die bemarkingsoudit gebruik. Objektiwiteit en kundigheid word as hoofredes hiervoor aangevoer. Ondernemings wat ' $n$ bemarkingsoudit gebruik beskou dit as ' $n$ belangrike hulpmiddel vir strategiese bemarkingsbestuur. Die gevolgtrekking word gemaak dat indien die resultate van hierdie studie beduidend is van die Suid-Afrikaanse situasie, die bemar. kingsoudit nog nie sy regmatige plek in die bedryfslewe ingeneem het nie.

S.Afr. Tydskr. Bedryfsl. 1984, 15: 225-228

L.F. Pitt* and P.G. Steyn

Department of Business Economics, University of Pretoria, Hillcrest, Pretoria, 0002 Republic of South Africa

R. Abratt

Graduate School of Business Administration, University of the Witwatersrand, Milner Park, Johannesburg, 2000 Republic of South Africa

*To whom correspondence should be addressed

\section{Introduction}

Every company must, at some time, undertake an in-depth review of its overall marketing effectiveness. The fact that it is the area of the firm which is in constant direct contact with an everchanging, dynamic market means that marketing is continually confronted with the possibility of rapid obsolescence of objectives, policies, strategies, and programmes. In many instances marketing effectiveness is not necessarily elucidated by current marketing results. Results may be due to the company being in the right place at the right time, rather than having effective marketing management - in fact, with effective management good results may have been excellent. At the risk of repeating clichés it is true to say that it is on rare occasions that there is no room for improvement.

As Philip Kotler has it: 'Each company should periodically reassess it's overall approach to the market place' (Kotler, 1984:761). In most instances the problem seems to be that management is so oriented towards its activities that it is not always able to ascertain whether these activities are being performed effectively or not.

\section{The marketing audit defined}

In an attempt to discover marketing weaknesses many firms have turned to undertaking a thorough study known as a marketing audit. Kotler defines the marketing audit as a comprehensive, systematic, independent and periodic examination of a company's or business units' marketing environment, objectives, strategies, and activities with a view to determining problem areas and opportunities and recommending a plan of action to improve the company's marketing performance (Kotler, 1984:765). The marketing audit clearly has four characteristics which distinguish it from mere management review or control processes. Firstly, it is comprehensive and therefore covers all the major marketing areas in a firm it does not simply stamp out fires. Secondly, it is systematic and involves a well laid-out sequence of diagnostic steps which should cover the firm's marketing environment, its internal systems, and each specific marketing activity. In the third instance, the marketing audit is seen as being independent. Perhaps objective would be a better choice of word. The purpose of the audit is not to provide lip-service or sing praises, but to provide constructive, objective criticism of the marketing spectrum in general, and of current marketing management practice in particular. Whether the firm uses an in-house team or outside auditors to conduct it is a matter of choice. Finally, the marketing audit is periodic and is not conducted only in good times, or only when sales have turned 
down. Ironically, companies are thrown into crises in many instances because they fail to review marketing effectiveness.

Kotler, Gregor \& Rodgers (1977:25-43) published an article in which they postulated that the marketing audit had indeed come of age in the United States. Whether the same can be said of South African companies is a matter of contention. This paper reports the results of a study conducted on South African companies in an effort to gauge the current status of the marketing audit.

\section{Methodology and the sample}

The research utilized a structured non-disguised questionnaire consisting of 16 questions which was mailed to 155 listed companies in the following sectors:

- Banks and financial services.

- Insurance.

- Chemicals and oils.

- Clothing, footwear and textiles.

- Electronics, electrical and battery.

- Engineering.

- Food.

- Motor.

- Paper and packaging.

- Pharmaceutical and medical.

- Steel and allied.

- Stores.

- Tobacco and match.

The marketing audit, as a concept, was defined (Kotler's definition) in the covering letter so that respondents should have experienced no problems in comprehending what was meant. This resulted in a response rate of $34,8 \%$, or 54 usable questionnaires which was considered particularly favourable for a mail questionnaire. A further 11 telephonic interviews were used to increase the response rate to $39,4 \%(n=65)$. While it may be argued that this is still a low reponse, the researchers are of the opinion that the information gathered offers a first, and useful, insight into marketing-audit practices of leading South African companies. It is furthermore of possible interest to add that respondents approached the research most positively and offered many interesting comments and observations. This was even among those companies not utilizing the marketing audit.

The information gathered in the research was divided into three categories:

- The extent of utilization of the marketing audit.

- The degree of independence.

- The importance of the marketing audit to users and the perceived advantages.

These categories are now discussed.

\section{The extent of utilization of the marketing audit}

Rather than simply determine what proportion of companies did and did not use the marketing audit, the approach here was three-pronged. Firstly, the questionnaire distinguished between those companies which had at some stage used a marketing audit and those which had never conducted one. These results are illustrated in Table 1.

Those companies which had never conducted an audit before were then asked why this had not been done, and the interview was then terminated. The answers to this question were of course many and varied, and one can almost sense the desperation of the respondent who answered, 'I have no idea'! Responses to this open question were broadly categorized by the researchers and are illustrated in Figure 1, in
Table 1 Utilization of the marketing audit $(n=65)$

\begin{tabular}{lc}
\hline & $\%$ \\
\hline Have never utilized the marketing audit & $55,4(36)$ \\
Have utilized the marketing audit & $44,6(29)$ \\
\hline
\end{tabular}

$\begin{array}{cl}\begin{array}{c}\text { Most } \\ \text { frequently } \\ \text { mentioned }\end{array} & \begin{array}{l}\text { Results are quite satisfactory without ever } \\ \text { having used a marketing audit. }\end{array} \\ \text { An instinctive self-evaluation is done at present } \\ \text { so that no special attention is given to this as it } \\ \text { seems unnecessary at present. } \\ \text { It is part of the strategic planning process - so } \\ \text { it is not formal. Also incorporated in the ac- } \\ \text { counting audit. } \\ \text { An audit at a given moment would quickly be- } \\ \text { come obsolete in our dynamic market situation. } \\ \begin{array}{l}\text { The company has sales problems and not } \\ \text { marketing problems - a sophisticated marketing } \\ \text { audit is not necessary. } \\ \text { frequently }\end{array} \\ \text { mentioned }\end{array}$

Figure 1 Reasons for never having used the marketing audit

frequency of mention. The relatively small sample and the diversity of response negated the need for quantification of this response.

It would be fair to say that the responses to this question are contrary to thoughts on the marketing audit in modern marketing literature. As Schuchman has it: 'Even the best can be made better. In fact the best must be made better, for few if any marketing operations can remain successful over the years by maintaining the status quo' (Schuchman, 1959:16-17).

Even the most lenient analysis of the responses to the question could not deny that the responses are innocent at best and short-sighted in the extreme.

Secondly, the analysis distinguished between those organizations which had utilized the marketing audit at some stage but had since ceased, and those who still conducted a marketing audit on a regular basis. This distribution is illustrated in Table 2.

It would seem that once a company has utilized the marketing audit and experienced the benefits it becomes part of management thinking. The three individual reasons proferred by companies who had suspended its use were given as follows:

- Results showed that marketing endeavours for specific products were successful and that further audits were unnecessary.

- Management is not committed to the further execution of audits.

- The marketing audit was viewed as a one-time project.

These responses are probably indicative of the fact that the marketing audit never really achieved its rightful place in any of these three companies. One of the characteristics of the marketing audit is that it is periodic, and for good

Table 2 Current utilization of the marketing audit $(n=29)$

\begin{tabular}{lc}
\hline & $\%$ \\
\hline Companies still utilizing the marketing audit & $89,6(26)$ \\
Companies no longer utilizing the marketing audit & $10,4(3)$ \\
\hline
\end{tabular}


reasons. That the audit in this limited number of cases was not periodic is perhaps evidence of the same shortsightedness evinced by companies not utilizing the audit.

Thirdly, those companies utilizing the marketing audit on a periodic basis were questioned as to how long they had been doing so. The answers to this question are summarized in Table 3.

Table 3 Time-span of use of the marketing audit $(n=26)$

\begin{tabular}{lc}
\hline Less than one year & $\%$ \\
One to two years & $7,65(2)$ \\
Two to five years & $26,9(7)$ \\
Longer than five years & $34,6(9)$ \\
Unknown period & $23,2(6)$ \\
\hline
\end{tabular}

It is evident from Table 3 that the majority of companies utilizing the marketing audit have been doing so for longer than a year. This supports our opinion that once a company has experienced the benefits gained from the marketing audit, it will continue to conduct marketing audits.

Companies utilizing the marketing audit periodically were asked, by means of an open question, why they had followed this approach. Responses to this question were categorized, and are to be found in Figure 2, in order of frequency mentioned.

$\begin{array}{cl}\begin{array}{c}\text { Most } \\ \text { frequently } \\ \text { mentioned }\end{array} & \begin{array}{l}\text { The dynamic environment with its threats and } \\ \text { opportunities makes a periodic review } \\ \text { imperative. A need to place matters in perspec- } \\ \text { tive, to react timeously. } \\ \text { A periodic need to identify gaps that may exist, } \\ \text { e.g. training needs. } \\ \text { Changing market and economic conditions mean } \\ \text { continuous changes in performance areas. } \\ \text { It is especially important to new firms or to } \\ \text { those with a complex product mix. } \\ \text { Least }\end{array} \quad \begin{array}{l}\text { Better marketing programmes can be developed, } \\ \text { and the resulting benefits exploited on a } \\ \text { continuous basis. }\end{array} \\ \text { mentioned } & \text { Marketing becomes more professional. }\end{array}$

Figure 2 Reasons for periodically conducting the marketing audit

\section{The degree of independence}

Having successfully identified those companies conducting marketing audits on a periodic basis, the next step was to discern the degree of independence in conducting the marketing audit.

Essentially the company has two options. Firstly, it can utilize its own personnel to conduct the audit, or secondly, it can use outside auditors. Expert opinion is that the best audits are likely to come from experienced outside consultants, who have the necessary objectivity and independence, broad experience in a number of industries and the undivided time and attention to give to the audit (Kotler, 1984:765).

The two basic options do of course offer a wide range of alternatives, the most commonly used of which is a combination of internal and external audit.

Table 4 offers a summary of the responses regarding the
Table 4 Use of internal/external persons to conduct the marketing audit $(n=26)$

\begin{tabular}{lccc}
\hline & $\%$ & Yes & No \\
\hline Are you availed of the necessary trained, & & & \\
qualified and able personnel to conduct & & 13 & 13 \\
the audit? & 42,3 & 11 & \\
Use internal staff only & 26,9 & 7 & \\
Use external parties only & 30,8 & 8 & \\
Use both internal and external parties &
\end{tabular}

degree of independence of the marketing audit.

It is evident from Table 4 that while 13 companies have the necessary staff to conduct the audit internally, only 11 actually use them exclusively. Also interesting to note is that eight firms use both internal and external auditors although this would imply that the internal staff may be there as 'watchdogs' or to learn, as they are by definition not suitable to conduct the complete audit at the present time.

Reasons for the use of internal staff were elicited by means of open question and are listed in order of frequency in Figure 3 (for both exclusive internal, and joint audits).

Reasons for the exclusive use of outsiders to conduct the marketing audit are to be found in Figure 4.

$\begin{array}{cl}\begin{array}{c}\text { Most } \\ \text { frequently } \\ \text { mentioned }\end{array} & \begin{array}{l}\text { Internal people have a better insight into } \\ \text { company activities. } \\ \text { Complements external audit and usually } \\ \text { reinforces external evaluation. } \\ \text { More effective, faster and less expensive. } \\ \text { Evokes interest of personnel, and protects their } \\ \text { role perceptions. } \\ \text { It is part of the marketing department's function. } \\ \text { freast }\end{array} \\ \text { Fontioned obvious reasons it can be performed more }\end{array}$

Figure 3 Reasons for the use of internal marketing audits

To obtain an objective and honest opinion.

They have the necessary skills and resources.

Time too limited to audit internally

Customers co-operate better with outside auditors.

Don't have suitable internal personnel.

International controlling companies require external audits.

Figure 4 Reasons for using external marketing auditors (in no order)

The final dimension of independence considered was the question of cost. Respondents were asked to indicate what the last audit conducted by external auditors had cost them. It may have been both interesting and useful to have asked whether the respondents felt that this had been money well spent. One does, however, gain the impression that the respondents were generally satisfied with outside auditors and felt that they had good reasons for using them.

Table 5 provides a breakdown of audit fees paid per last audit to external auditors.

The importance of the marketing audit to users and the perceived advantages

It is evident from Table 6 that respondents regarded the marketing audit as either being most important or important. 
Table 5 Expenditure on last external audit $(n=15)$

\begin{tabular}{rc}
\hline $\begin{array}{c}\text { Cost category } \\
(\mathbf{R})\end{array}$ & $\%$ of respondents \\
\hline $0-5000$ & $6,7(1)$ \\
$5001-10000$ & $33,3(5)$ \\
$10001-20000$ & $26,7(4)$ \\
$20001-30000$ & $13,3(2)$ \\
$>30001$ & $20,0(3)$ \\
\hline
\end{tabular}

Table 6 Importance of the marketing audit $(n=26)$

\begin{tabular}{lc}
\hline Degree of importance & $\%$ \\
\hline Very important & $61,5(16)$ \\
Important & $38,5(10)$ \\
Not very important & 0 \\
Not important at all & 0 \\
\hline
\end{tabular}

There were no responses to the two other alternatives on the four-point scale used.

It is thus obvious that the marketing audit is regarded as important by those companies using it. This was to be expected - it would be somewhat irrational to conduct a marketing audit if it were not regarded as important. Motivation for conducting the audit was also elicited and once again fairly predictable responses resulted. Respondents were given four alternatives and asked to mark the most important reason for conducting a marketing audit. The results are shown in Table 7.

Table 7 Most important reason for conducting the marketing audit $(n=26)$

\begin{tabular}{lc}
\hline Reason & $\%$ \\
\hline An attempt to achieve better marketing results & $65,4(17)$ \\
An evaluation of marketing personnel & 26,9 (7) \\
Recommended by someone & 3,85 (1) \\
A crisis in the company & 3,85 (1) \\
\hline
\end{tabular}

An indication of the positive response and high interest level of respondents was the fact that a number of respondents regarded the above alternatives as too limiting and added more reasons of their own. (The alternatives offered probably were too limiting. This was, however, a deliberate attempt to save respondent time and solve processing problems.) Among the more interesting other reasons given were:

- In order to identify new opportunities;

- the entry of a competitor into a hitherto monopolistic market;

- in order to ensure that specifically designed marketing programmes were being interpreted by customers as such.

\section{Conclusion}

This article has reported the findings of a study of some aspects of the use of marketing audits by South African companies. The major limitation of this exploratory study is of course the small sample, which covered only companies listed on the Johannesburg Stock Exchange. While a broader study of non-listed companies would obviously yield more accurate, and of course more interesting results, it is doubtful whether they would differ markedly. The companies surveyed are generally larger than the median non-listed company and market leaders in many instances. One would expect them to be trend-setters rather than followers.

As an adjunct to this, it is interesting to consider that the percentage of respondents utilizing the marketing audit may be disproportionately high. Non-respondents may be companies who have never used the audit and are loathe or disinterested to admit it. On the other hand one did gain the impression from unsolicited comments by user respondents that they were rather (and justifiably so) proud of their audit implementation and wanted very much to convey this.

In summary it can be said that the majority of respondents do not utilize the marketing audit. In many instances this is unfortunately as a result of overconfidence and selfsatisfaction. Some companies had dropped the use of the marketing audit for shortsighted reasons, and did not view it as a periodic exercise.

Those companies utilizing the marketing audit had, in most instances, used it for a period of longer than one year. Strategic considerations had in most instances been the major motivation for the continued use of the marketing audit.

While half the companies utilizing the marketing audit do have adequately qualified and experienced personnel, the majority used outside expertise, either exclusively or in conjunction with own staff, to conduct it. Reasons given for the exclusive use of inside audits were amongst others better insight, costs, and that it was marketing personnel's job. The use of outside auditors was motivated by factors such as objectivity, expertise and resources, time saving, and greater customer acceptability - these factors tend to support Kotler's recommendation of the independent audit (Kotler, 1984:765).

Most of the companies utilizing the audit regarded it as very important, with the rest regarding it as important. In most instances the audit had been motivated by an attempt to achieve better marketing results. Less important reasons were in order to evaluate marketing personnel, because it was recommended, and a crisis in the company.

Has the marketing audit come of age in South Africa? The results of this study seem to deny that the marketing audit is accorded its rightful role in the strategic marketing management of the majority of South African companies. The dynamic and complex South African marketing environment will dictate that companies utilize a comprehensive systematic, independent, and periodic marketing audit. Marketing effectiveness is characterized by customer orientation, integrated marketing organization, adequate marketing information, a strategic orientation and operational efficiency. The time has perhaps come for the South African firm to ask not whether it can afford to conduct a marketing audit but whether it can afford not to.

\section{References}

Kotler, P. 1984. Marketing Manugement: Analysis, planning and control. Englewood Cliffs, New Jersey: Prentice-Hall, Inc. 5th edition.

Kotler, P., Gregor, W. \& Rodgers, W. 1977. The marketing audit comes of age. In Sloan Management Review.

Schuchman, A. 1959. The marketing aldit: Its nature, purposes and problems. In Oxenfeldt, A. and Crisp, R.D., Analysing and improving market performance, Report No. 32, New York: American Management Association. 